\title{
LHX3 wt Allele
}

National Cancer Institute

\section{Source}

National Cancer Institute. LHX3 wt Allele. NCI Thesaurus. Code C104956.

Human LHX3 wild-type allele is located in the vicinity of $9 q 34.3$ and is approximately $9 \mathrm{~kb}$ in length. This allele, which encodes LIM/homeobox protein LHX3, is a transcription factor involved in motor neuron specification and pituitary development. Mutations in this gene are associated with combined pituitary hormone deficiency 3. 